\title{
Cumulative Incidence of Self-Reported Diabetes in Croatian Adult Population in Relation to Socioeconomic Status and Lifestyle Habits
}

\author{
Tamara Poljičanin ${ }^{1}$, Mario Šekerija ${ }^{2}$, Jozo Boras ${ }^{1}$, Branko Kolarićé,4, Silvije Vuletić ${ }^{5}$ and \\ Željko Metelko ${ }^{1,6}$ \\ ${ }^{1}$ University of Zagreb, Merkur University Hospital, Vuk Vrhovac University Clinic, Zagreb, Croatia \\ ${ }^{2}$ Croatian National Institute of Public Health, Zagreb, Croatia \\ ${ }^{3}$ Zagreb County Institute of Public Health, Velika Gorica, Croatia \\ ${ }^{4}$ University of Rijeka, School of Medicine, Rijeka, Croatia \\ ${ }^{5}$ University of Zagreb, School of Medicine, »Andrija Štampar« School of Public Health, Zagreb, Croatia \\ ${ }^{6}$ University of Zagreb, School of Medicine, Zagreb, Croatia
}

\begin{abstract}
A B S T R A C T
The aim of this study was to determine the 5-year cumulative incidence of self-reported diabetes mellitus in relation to various socioeconomic and lifestyle factors in Croatian adult population. The analysis included 2909 participants of the Croatian Health Cohort Study (CroHort) aged 20-79 years (median 55, interquartile range 43-67; 69\% women) with no history of diabetes. There were 163 new cases of diabetes (5-year cumulative incidence 5.6\%), without significant differences according to sex. Significant predictors of diabetes were age, body mass index, waist and hip circumference in bivariate logistic regression, and being married or living in partnership (OR=1.57, 95\% CI 1.08-2.28; $p=0.018)$, body mass index $(O R=1.11,95 \%$ CI 1.07-1.14; $p<0.001)$ and age $(O R=1.02,95 \%$ CI 1.01-1.03; $p=0.004)$ in multivariate model. Our results indicate that approximately $1 \%$ of the Croatian adult population develops diabetes each year. Association of living in partnership with higher diabetes incidence requires further investigation.
\end{abstract}

Key words: diabetes mellitus, incidence, marital status, dietary habits, morbidity, CroHort study

\section{Introduction}

The prevalence of diabetes mellitus (DM) is increasing worldwide. It is estimated that 235 million people have diabetes in 2010, and their number is expected to increase to 438 million by $2030^{1}$. Factors that contribute to the rising prevalence include prolonged survival of individuals with diabetes, screening programs, lowering of diagnostic criteria, growing attention to the disease which increases awareness and, last but not least, rising incidence of type 2 diabetes ${ }^{2}$. Sedentary way of life, rising prevalence of obesity ${ }^{3}$ and lack of physical activity ${ }^{4}$ are the major risk factors contributing to the increasing diabetes incidence. Incidence rates of diabetes ranged from 7.6 per 1000 person-years (PY) in Italy ${ }^{5}, 13$ per 1000 PY in the Netherlands ${ }^{6}$ to 21 per $1000 \mathrm{PY}$ in a high-risk population such as Mauritians ${ }^{7}$. Incidence rates of self-reported DM are usually lower than those obtained by oral glucose tolerance tests ${ }^{8}$, although they are rising, as documented by the age-adjusted incidence rates of diabetes from the United States Behavioural Risk Factors Surveillance System (BRFSS), which increased from 4.8/1000 PY in the 1995-1997 survey to 9.1/1000 PY in that from 2005-20079.

Several studies have indicated that the prevalence of diabetes is higher in groups with low socioeconomic status (SES) ${ }^{10}$, with excess morbidity and mortality when compared to groups with higher SES. Determinants of SES which are found to be important in relation to the prevalence and complications of diabetes mellitus include income, education ${ }^{11}$, occupation ${ }^{12}$ and ecological measures of poverty ${ }^{10}$. The majority of the studies on the relationship between SES and DM have focused on the 
prevalence of diabetes, while fewer have concentrated on the relationship between the incidence of DM and SES. Determinants of SES related to diabetes incidence are similar to those for diabetes prevalence. In addition, many classical risk factors that contribute to diabetes incidence, such as physical inactivity or increased body mass index are often intermediate factors of lower $\mathrm{SES}^{13}$. The prevalence of diabetes in Croatia is $6.1 \%$ in the 18-65-year age group ${ }^{14}$, with a high prevalence of obe$\operatorname{sity}^{15}$. There are data on the incidence of type 1 diabetes in Croatian children ${ }^{16,17}$, but those on adult population are still lacking. Our study was aimed at determining the cumulative incidence of diabetes in a 5-year period and exploring the relationship between patterns of SES, lifestyle factors and self-reported diabetes incidence in a large sample of the Croatian population.

\section{Patients and Methods}

This study was a part of the Croatian Health Cohort Study (CroHort), a repeated cross-sectional survey of Croatian adults aimed at providing a comprehensive community health assessment of Croatians, including their access to and use of health care services, health status, and determinants of health such as nutrition, physical activity, smoking, and alcohol consumption. The study was approved by the Research Ethics Committee, School of Medicine, University of Zagreb, grant number 04-1060-2006. Data were collected by community nurses trained for interviewing. The complete design of the CroHort study is described elsewhere ${ }^{18,19}$. For the purposes of this investigation we included 2909 20-79-yr old respondents without diabetes mellitus on initial visit in 2003 .

To investigate the incidence of DM, data on diabetes status (defined as patients' self-reported history of »elevated sugar « and taking of drug treatment for diabetes within the last week) were taken from the 2008 visit. Data on sex, age, level of education, self-evaluation of financial status, employment status, marital status, diet, physical activity, waist and hip circumference and body mass index were gathered from the baseline visit.

The level of education was categorized into 3 groups (unfinished + finished primary school, high school or similar, college or university). Financial status was categorized as below average, average and above average. Employment was defined as yes or no, while marital status was categorized into married or living in partnership and other (including being single, separated or divorced and widowed). Body mass index was calculated as weight (kg) divided by squared height $\left(\mathrm{m}^{2}\right)$. Subjects who reported at least two of the following risks were considered as having an unhealthy diet: consumption of animal fat, milk and dairy products with more than $1.5 \%$ of fat, eating sweets every day, not eating fruit every day and always adding salt to food. Subjects who reported at least two of the following risk factors were considered as physically inactive: working at home, travelling to work by public transport, or working within a 15-min walking or cycling distance, easy or a very easy job (sedentary or walking), physical activity less than 30 min a day during leisure time, advice received from a health care professional within the past year to increase physical activity.

\section{Statistical analyses}

All statistical analyses were performed using SAS (version 9.1.3). Normality of distribution was tested using Shapiro-Wilks test. Differences between groups of independent continuous variables were analyzed using t-test or Mann-Whitney U test while distributions of categorical predictors were compared using chi-square tests. Cumulative incidence of diabetes was calculated by dividing the number of incident diabetes cases by total number of persons who were diabetes free at baseline.

For the prediction of the probability of diabetes occurrence logistic regression analysis with best subset selection of predictors was performed. Variables with $p<0.2$ in bivariate regression were included in multivariate model, except for waist and hip circumference, given its high correlation with body mass index (Spearman coefficient of correlation $0.77 ; \mathrm{p}<0.001$ ). The final model was constructed by backward stepwise method using $p$ value of 0.1 as a significance level for removal from the model. Statistical significance was defined as a $\mathrm{p}$ value less than 0.05 ( $\mathrm{p}<0.05$; two-tailed).

\section{Results}

There were 2909 persons without DM at baseline (2003), 2012 (69\%) of them being women. Median age was 55 years (interquartile range 43-67) with median BMI of $26.6 \mathrm{~kg} / \mathrm{m}^{2}$ (interquartile range 23.9-30.0). Participants with new-onset DM were significantly older at baseline $(p<0.001)$, less frequently employed $(p=0.011)$, with greater waist and hip circumference and higher BMI (all $\mathrm{p}<0.001$ ). There were no differences according to $\operatorname{sex}(p=0.964)$, self-evaluation of financial status $(p=0.988)$, marital status $(p=0.110)$, level of education $(p=0.174)$, physical activity $(p=0.638)$ and diet $(p=0.233)$ between the participants with new-onset diabetes and those without diabetes. Differences between the groups with and without the onset of diabetes mellitus during the follow-up period are presented in Table 1.

In 2008, 163 persons reported having diabetes (cumulative 5-year incidence $=5.60 \%$; 95\% CI 4.82-6.50), 113 women (cumulative 5-year incidence $5.62 \%$; $95 \%$ CI 4.70-6.71) and 50 men (cumulative incidence 5.57\%; 95\% CI 4.25-7.27). Cumulative 5-year incidence by sex and age and corresponding confidence intervals are presented in Table 2.

For men, cumulative incidence was highest in the 50-64 age group, while women showed highest cumulative incidence in the 65-79 age group. In comparison to younger age groups, cumulative incidence was twice as high in the age groups over 50 years in both sexes.

Bivariate logistic regression analysis suggested that age, employment status, waist and hip circumference and BMI were significant predictors of the development 
TABLE 1

BASELINE CHARACTERISTICS OF THE GROUPS WITH AND WITHOUT NEW-ONSET DIABETES MELLITUS DURING THE FOLLOW-UP

\begin{tabular}{|c|c|c|c|}
\hline & New DM & No DM & $\mathrm{p}$ \\
\hline Age (years)* & $60(52-68)$ & $54(43-67)$ & 0.001 \\
\hline $20-34$ & $11(6.8 \%)$ & $344(12.5 \%)$ & $<0.001$ \\
\hline $35-49$ & $23(14.1 \%)$ & $691(25.2 \%)$ & \\
\hline $50-64$ & $68(41.7 \%)$ & $891(32.4 \%)$ & \\
\hline $65-79$ & $61(37.4 \%)$ & $820(29.9 \%)$ & \\
\hline \multicolumn{4}{|l|}{ Sex } \\
\hline men & $50(30.7 \%)$ & $847(30.8 \%)$ & 0.964 \\
\hline women & $113(69.3 \%)$ & $1899(69.2 \%)$ & \\
\hline \multicolumn{4}{|l|}{ Financial status } \\
\hline Lower then average & $69(42.6 \%)$ & $1186(43.2 \%)$ & \multirow{3}{*}{0.988} \\
\hline Average & $76(46.9 \%)$ & $1272(46.3 \%)$ & \\
\hline Higher than average & $17(10.5 \%)$ & $287(10.5 \%)$ & \\
\hline \multicolumn{4}{|l|}{ Employed } \\
\hline No & $126(77.3 \%)$ & $1860(67.7 \%)$ & \multirow[t]{2}{*}{0.011} \\
\hline Yes & $37(22.7 \%)$ & $886(32.3 \%)$ & \\
\hline \multicolumn{4}{|l|}{ Level of education } \\
\hline$\leq 8$ years & $82(50.3 \%)$ & $1178(43.0 \%)$ & \multirow{3}{*}{0.174} \\
\hline $9-12$ years & $62(38.0 \%)$ & $1225(44.7 \%)$ & \\
\hline$>12$ years & $19(11.7 \%)$ & $338(12.3 \%)$ & \\
\hline \multicolumn{4}{|l|}{ Marital status } \\
\hline Married & $117(71.8 \%)$ & $1802(65.7 \%)$ & \multirow[t]{2}{*}{0.110} \\
\hline Not married & $46(28.2 \%)$ & $942(34.3 \%)$ & \\
\hline \multicolumn{4}{|l|}{ Physical activity } \\
\hline Active & $109(66.9 \%)$ & $1884(68.6 \%)$ & \multirow[t]{2}{*}{0.638} \\
\hline Inactive & $54(33.1 \%)$ & $861(31.4 \%)$ & \\
\hline \multicolumn{4}{|l|}{ Diet } \\
\hline Healthy & $144(88.3 \%)$ & $2332(84.9 \%)$ & \multirow[t]{2}{*}{0.233} \\
\hline Unhealthy & $19(11.7 \%)$ & $414(15.1 \%)$ & \\
\hline Waist circumference $(\mathrm{cm})^{*}$ & $100(91.5-110)$ & $94(84-103)$ & $<0.001$ \\
\hline Hip circumference $(\mathrm{cm}) *$ & $110(104-119.5)$ & $106(100-114)$ & $<0.001$ \\
\hline Body mass index $\left(\mathrm{kg} / \mathrm{m}^{2}\right)^{*}$ & 29.37 (25.97-32.87) & $26.49(23.78-29.74)$ & $<0.001$ \\
\hline
\end{tabular}

Data are presented as number of participants (percent) unless noted otherwise, * median (interquartile range)

of DM. Multivariate logistic regression model suggested that being married or living in partnership, BMI and age were significant predictors of the development of DM.
The odds for the development of DM in the multivariate analysis were highest with being married or living in partnership (OR 1.568), followed by BMI (OR=1.107)

TABLE 2

AGE-SPECIFIC 5-YEAR CUMULATIVE INCIDENCE OF DIABETES ACCORDING TO SEX

\begin{tabular}{|c|c|c|c|c|c|c|}
\hline \multirow{2}{*}{ Age } & \multicolumn{2}{|c|}{ Men } & \multicolumn{2}{|c|}{ Women } & \multicolumn{2}{|c|}{ All } \\
\hline & incidence $(\%)$ & $95 \%$ CI & incidence(\%) & $95 \% \mathrm{CI}$ & incidence $(\%)$ & $95 \% \mathrm{CI}$ \\
\hline $20-34$ & 3.49 & $1.19-9.76$ & 2.97 & $1.51-5.75$ & 3.10 & $1.74-5.46$ \\
\hline $35-49$ & 3.70 & $1.89-7.13$ & 3.01 & $1.83-4.91$ & 3.22 & $2.15-4.79$ \\
\hline $50-64$ & 7.26 & $4.84-10.75$ & 7.01 & 5.30-9.22 & 7.09 & $5.63-8.89$ \\
\hline $65-79$ & 5.82 & $3.66-9.12$ & 7.47 & $5.61-9.88$ & 6.92 & $5.42-8.79$ \\
\hline Total & 5.57 & $4.25-7.27$ & 5.62 & $4.70-6.71$ & 5.60 & $4.82-6.50$ \\
\hline
\end{tabular}


TABLE 3

BIVARIATE LOGISTIC REGRESSION FOR NEW DM AS AN OUTCOME

\begin{tabular}{lccc}
\hline & Odds Ratio & $95 \%$ CI & $\mathrm{p}$ \\
\hline Age & 1.020 & $1.008-1.032$ & 0.001 \\
\hline $\begin{array}{l}\text { Sex } \\
\text { male }\end{array}$ & 1 & & \\
female & 1.008 & $0.716-1.420$ & 0.964 \\
\hline
\end{tabular}

Financial status

lower than average

average 1.027

higher than average

1.027

1.018

$0.734-1.436$

0.876

$0.590-1.758$

0.949

Level of education

$\leq 8$ years

9-12 years

1

$>12$ years

0.727

0.808

0.518-1.021

0.066

Employed

1

Unemployed

1.623

$1.115-2.358$

0.011

Widowed, separated/

divorced or single

Married or living

in partnership

1

$1.330 \quad 0.937-1.887$

0.111

\begin{tabular}{|c|c|c|c|}
\hline Physical activity & 1 & & \\
\hline Physical inactivity & 0.922 & $0.659-1.291$ & 0.638 \\
\hline Healthy diet & 1 & & \\
\hline Unhealthy diet & 1.345 & $0.825-2.196$ & 0.235 \\
\hline Waist circumference & 1.035 & $1.023-1.046$ & $<0.001$ \\
\hline Hip circumference & 1.030 & $1.017-1.043$ & $<0.001$ \\
\hline Body mass index & 1.114 & $1.081-1.148$ & $<0.001$ \\
\hline
\end{tabular}

TABLE 4

MULTIVARIATE LOGISTIC REGRESSION MODEL FOR NEW DM AS AN OUTCOME

\begin{tabular}{lrcr}
\hline & $\begin{array}{r}\text { Odds } \\
\text { Ratio }\end{array}$ & $95 \%$ CI & p \\
\hline Married or living in partnership & 1.568 & $1.079-2.280$ & 0.018 \\
BMI & 1.107 & $1.073-1.141$ & $<0.001$ \\
Age & 1.019 & $1.006-1.032$ & 0.004 \\
\hline
\end{tabular}

and then age which was associated with the odds ratio of 1.019. Data from the bivariate and multivariate logistic regression analysis are presented in Table 3 and Table 4.

\section{Discussion and Conclusion}

The results of this study reveal higher cumulative incidence of self-reported DM than expected. There were no significant differences according to sex, while age distribution of new cases of diabetes demonstrated that diabetes incidence peaked at an earlier age in men (50-64 yrs.) than in women. Although the incidence was comparable in the 50-64-yr age group, it declined in 65-79-yr old men, while in women it continued to rise. This might be attributed to different perception of diabetes in the elderly, women showing more concern about diabetes, having more preventive check-ups and being more compliant about diabetes therapy in comparison with men. However, since majority of study participants were women, the confidence intervals for the cumulative incidence of diabetes for men are wider and less precise and the sex difference is not statistically significant between age groups.

The cumulative incidence obtained in our study was comparable to previously published reports based on diagnostic criteria which include blood glucose measurements. However, they were somewhat higher than those in the predominantly Caucasian population ${ }^{20,21}$ and lower than in the Middle East population ${ }^{22}$, but also higher than the previously reported rates of self-reported diabetes ${ }^{8,9}$.

Studies using self-reported diabetes often underestimate true prevalence and incidence of diabetes due to surveillance bias or confounding by indication. However, in the recent years there has been an increased awareness owing to public health programs focused on diabetes. Better knowledge and awareness of diabetes could possibly explain higher self-reported cumulative incidence than expected in such surveys, higher even than those in the USA ${ }^{9}$.

Results from epidemiologic studies strongly point to the association between obesity and the development of type $2 \mathrm{DM}$ in both men and women ${ }^{23-25}$, literature data strongly suggesting that lifestyle interventions can prevent or delay the onset of type $2 \mathrm{DM}^{26}$. Our data also suggest that higher BMI, and waist and hip circumference are associated with a significantly higher risk for the development of diabetes, as expected. Physical inactivity ${ }^{27}$ and unhealthy $\operatorname{diet}^{28}$ have also been associated with a higher risk of incident DM. In our study, physical inactivity, the risk factor with a very high prevalence in Croatian diabetic subjects ${ }^{29}$, was not shown to be a significant predictor of diabetes and neither was unhealthy diet.

Unemployment was associated with a higher risk of $\mathrm{DM}$; however, this association diminished when age was controlled for. Differences across categories of financial status and level of education did not reach statistical significance.

The association of marital status with the development of new-onset diabetes was an unexpected finding of this study. Previous studies have shown that individuals who are widowed, divorced/separated or single are more prone to diabetes development due to unhealthy lifestyle, lack of social support and stress. We hypothesize that the greater rate of diabetes in married individuals in our study is due to our definition of diabetes state. Since it included taking of diabetes medication within the last week, those who were more compliant with therapy would have been classified as diabetics, while those who, for various reasons, were not taking their pills would not have been recognized. Married individuals are known to 
have higher pharmacological therapy compliance rates [30], which could partly explain this phenomenon.

Limitations of this study include the use of self-reported diabetes treated by medications as a definition of DM. Previous studies have reported that between one-quarter and one-half of people diagnosed with diabetes denies it in health questionnaires ${ }^{31-33}$, with specificity being much higher than sensitivity for the diagnosis of diabetes, while higher education levels are associated with better self-report ${ }^{34,35}$.

In view of this and due to the fact that the question "Do you have elevated sugar? « might also include those with IFG or IGT or the combination and exclude those with a well-regulated DM treated by medications, we opted to include both questions in the definition. This could have excluded patients with diagnosed DM on diet and lifestyle modification therapy alone. According to data from CroDiab, the national diabetes registry, the percentage of such patients is merely $8 \%{ }^{36}$ and with regard to that we believe that estimate of diabetes with taking of diabetes medication is more accurate for the purpose of this study. Earlier studies have confirmed the use of the syntagm "treated diabetes" as being sufficiently accurate for use in epidemiologic studies ${ }^{37}$.

Another limitation is the fact that over $2 / 3$ of the study participants were women. This was taken into ac- count and analyses were stratified by gender, whereas sex was taken as a possible confounder in the regression model used. Furthermore, diabetes status was not assessed between visits so we calculated only cumulative 5 -year incidence.

Incidence of DM in Croatia reported in this study is relatively high in comparison to previous studies. The problem of a growing number of Croatian patients with diabetes and its adverse effects on health and society demands an integrative approach with various components of health-care and system strategies included. Special attention must be paid to population-oriented preventive actions in order to address this increasing burden. The finding of an increased risk of the development of DM associated with marital status requires further investigation to establish whether this is the effect of improved diagnosis and treatment in that part of the Croatian population or some other, as yet unrecognized factor.

\section{Acknowledgements}

This manuscript is prepared within the project of the Ministry of Science, Education and Sports, Grant \# 108-1080135-0264.

\section{R E F E R E N C E S}

1. SHAW JE, SICREE RA, ZIMMET PZ, Diabetes Res Clin Pract, 87 (2010) 4. - 2. BURKE J, WILLIAMS K, GASKILL S, HAZUDA H, HAFFNER S, STERN M, Arch Intern Med, 159 (1999) 1450. - 3. MOKDAD AH, FORD ES, BOWMAN BA, DIETZ WH, VINICOR F, BALES VS, MARKS JS, JAMA, 289 (2001) 76. - 4. KRISKA AM, SAREMI A, HANSON RL, BENNETT PH, KOBES S, WILLIAMS DE, KNOWLER WC, Am J Epidemiol, 158 (2003) 669. — 5. BONORA E, KIECHL S, WILLEIT J, OBERHOLLENZER F, EGGER G, MEIGS JB, BONADONNA RC MUGGEO M, Diabetes, 53 (2004) 1782. - 6. DE VEGT F, DEKKER JM JAGER A, HIENKENS E, KOSTENSE PJ, STEHOUWER CDA, NIJPELS G, BOUTER LM, HEINE RJ, JAMA, 285 (2001) 2109. — 7. SÖDERBERG S, ZIMMET P, TUOMILEHTO J, DE COURTEN M, DOWSE GK, CHITSON P, STENLUND H, GAREEBOO H, ALBERTI KG, SHAW J, J Intern Med, 256 (2004) 37. - 8. MEISINGER C, THORAND B, SCHNEIDER A, STIEBER J, DÖRING A, LÖWEL H, Arch Intern Med, 162 (2002) 82. 9. Centers for Disease Control and Prevention (CDC), MMWR Morb Mortal Wkly Rep, 57 (2008) 1169. - 10. EVANS JM, NEWTON RW, RUTA DA, MACDONALD TM, MORRIS AD, Diabet Med, 17 (2000) 478. — 11 ROBBINS J, VACCARINO V, ZHANG H, KASL S, Am J Public Health, 91 (2001) 76. - 12. MOKDAD AH, BOWMAN BA, FORD ES, VINICOR F, MARKS JS, KOPLAN JP, JAMA, 286 (2001) 1195. - 13. KRISHNAN S, COZIER YC, ROSENBERG L, PALMER JR, Am J Epidemiol, 171 (2010) 564. - 14. METELKO Ž, PAVLIĆ-RENAR I, POLJIČANIN T, SZIROVITZA L, TUREK S, Diabetes Res Clin Pract, 81 (2008) 263. - 15. FIŠTER K, KOLČIĆ I, MILANOVIĆ SM, KERN J, Coll Antropol, 33 (2009) S25. - 16. STIPANČIĆ G, LA GRASTA SABOLIĆ L, MALENICA M, RADICA A, ŠKRABIĆ V, TILJAK MK, Diabetes Res Clin Pract, 80 (2008) 122. - 17. ROGLIĆ G, METELKO Ž, KADRNKA-LOVRENČIĆ M, RADICA A, PRASEK M, Diabetol Croat, 24 (1995) 145. — 18. VULETIĆ S, POLAŠEK O, KERN J, STRNAD M, BAKLAIĆ Ž, Coll Antropol, 33 (2009) S3. - 19. IVICEVIĆ-UHERNIK A, VULETIĆ S, KERN J, DECKOVIĆ-VUKRES V, MIHEL S, ERCEG M, PRISTAŠA I, Coll Antropol, 36 (2012) Suppl. 1: 3. - 20. FOROUHI NG, LUAN J, HENNINGS S, WAREHAM
NJ, Diabet Med, 24 (2007) 200. - 21. MAGLIANO DJ, BARR EL, ZIMMET PZ, CAMERON AJ, DUNSTAN DW, COLAGIURI S, JOLLEY D, OWEN N, PHILLIPS P, TAPP RJ, WELBORN TA, SHAW JE, Diabetes Care, 31 (2008) 267. - 22. HARATI H, HADAEGH F, SAADAT N, AZIZI F, BMC Public Health, 9 (2009) 186. - 23. HAFFNER SM, STERN MP, MITCHELL BD, HAZUDA HP PATTERSON JK, Diabetes, 39 (1990) 283 - 24. HOLBROOK TL, BARRETT-CONNOR E, WINGARD DL, Int J Obes, 13 (1989) 723. — 25. FIELD AE, COAKLEY EH, MUST A, SPADANO JL, LAIRD N, DIETZ WH, RIMM E, COLDITZ GA, Arch Intern Med, 161 (2001) 1581. - 26. EMINI-SADIKU M, CAR N, METELKO Ž BAJRAKTARI G, MORINA N, DEVOLLI D, Diabetol Croat, 37 (2008) 23 - 27. SIGAL RJ, KENNY GP, WASSERMAN DH, CASTANEDA-SCEPPA C, WHITE RD, Diabetes Care, 29 (2006) 1433. — 28. BRUNNER EJ, MOSDØL A, WITTE DR, MARTIKAINEN P, STAFFORD M, SHIPLEY MJ, MARMOT MG, Am J Clin Nutr, 87 (2008) 1414. - 29. MAGAŠ S, POLJIČANIN T, ŠEKERIJA M, AJDUKOVIĆ D, METELKO Z, CAR N, KERN J, Coll Antropol, 33 (2009) S115 - 30. TRIVEDI RB, AYOTTE B, EDELMAN D, BOSWORTH HB, J Behav Med, 31 (2008) 489. - 31. MOLENAAR EA, VAN AMEIJDEN EJ, GROBBEE DE, NUMANS ME, Eur J Public Health, 17 (2007) 199. - 32. WU SC, LI CY, KE DS, Public Health, 114 (2000) 137. - 33. MARTIN LM, LEFF M, CALONGE N, GARRETT C, NELSON DE, Am J Prev Med, 18 (2000) 215. — 34. MACKENBACH JP, LOOMAN CW, VAN DER MEER JB, Am J Public Health, 86 (1996) 706. - 35. KRIEGSMAN DM, PENNINX BW, VAN EIJK JT, BOEKE AJ, DEEG DJ, J Clin Epidemiol, 49 (1996) 1407. — 36. CroDiab [Internet]. Zagreb: The Vuk Vrhovac University Clinic; [revised 2008; accesses 31. 5.2010.]. Broj godišnjih prijava u CroDiab registru [Number of annual CroDiab registrations]; p. 7. Available from: URL: http://www.idb.hr/cdw 2008. pdf System Requirements: Adobe Acrobat. 37. MARGOLIS KL, LIHONG QI, BRZYSKI R, BONDS DE, HOWARD BV, KEMPAINEN S, SIMIN LIU, ROBINSON JG, SAFFORD MM, TINKER LT, PHILLIPS LS; WOMEN HEALTH INITIATIVE INVESTIGATORS, Clin Trials, 5 (2008) 240. 


\section{T. Poljičanin}

University of Zagreb, Merkur University Hospital, Vuk Vrhovac University Clinic, Zajčeva 19, 10000 Zagreb, Croatia e-mail: tamara.poljicanin@idb.hr

\section{POVEZANOST KUMULATIVNE INCIDENCIJE ŠEĆERNE BOLESTI SA SOCIOEKONOMSKIM STATUSOM I ŽIVOTNIM NAVIKAMA U ODRASLOJ POPULACIJI HRVATSKE: CROHORT STUDIJA}

\section{S A ̌̌ E T A K}

Cilj ovog istraživanja bio je utvrditi petogodišnju kumulativnu incidenciju samoprijavljene šećerne bolesti u povezanosti s raznim socioekonomskim i životnim čimbenicima u Hrvatskoj. Istraživanjem je obuhvaćeno 2909 osoba koje su sudjelovale u Croatian Health Cohort Study (CroHort), s medijanom starosti od 55 godina (interkvartilni raspon 43-67; 69\% žena), bez šećerne bolesti na prvom pregledu. U tijeku studije 163 ispitanika razvilo je šećernu bolest (petogodišnja kumulativna incidencija 5,6\%) bez značajnih razlika prema spolu (muškarci 5,57\%, žene 5,62\%; p=0,964). Najviša petogodišnja incidencija zabilježena je kod muškaraca u dobnoj skupini 50-64 godine (7,26\%) i kod žena u dobnoj skupini od 65-79 godina (7,47\%). U bivarijatnoj logističkoj regresiji dob, indeks tjelesne mase, opseg struka i bokova te zaposlenost su bili značajni prediktori razvoja šećerne bolesti. U multivarijatnom modelu značajni prediktori razvoja dijabetesa bili su život u partnerstvu ili oženjen status $(\mathrm{OR}=1,57,95 \%$ CI $1,08-2,28 ; \mathrm{p}=0,018)$, indeks tjelesne mase $(O R=1,11,95 \%$ CI 1,07-1,14; $p<0,001)$ i dob $(O R=1,02,95 \%$ CI 1,01-1,03; $p=0,004)$. Naši rezultati ukazuju da oko $1 \%$ hrvatske odrasle populacije razvija šećernu bolest i započinje farmakološko liječenje svake godine. Povezanost bračnog statusa ili života u partnerstvu s višom incidencijom šećerne bolesti zahtijeva daljnja istraživanja. 